\title{
Crop Wild Relatives of Genus Coriandrum L. in Georgia (South Caucasus)
}

\author{
Maia Akhalkatsi* and Tamar Girgvliani \\ Department of Plant Genetic Resources, Ilia State University, Republic of Georgia
}

Submission: March 08, 2017; Published: May 30, 2017

"Corresponding author: Maia Akhalkatsi, Head of Department of Plant Genetic Resources, Institute of Botany, Ilia State University, Faculty of Natural Sciences and Engineering, K Cholokashvili 3/5, 0162 Tbilisi, Republic of Georgia, Email: maia_akhalkatsi@iliauni.edu.ge

\begin{abstract}
Coriander - Coriandrum sativum L., genus Coriandrum L., family Apiaceae; is agricultural species and many species with this genus are as crop wild relatives (CWRs). Rural vegetation is one of the most interesting in terms of CWR. This is especially important for fodder species, such as Coriandrum sativum, Aethusa cynapium, Bifora radians, Cicuta virosa, Conium maculatum, Physospermum cornubiense, Sium latifolium and Smyrnium cicutarium. These oll species are for food and as medicinal plants with many vitamins - A, B1, B2, B3, B5, B6, B9, C, E and K. Fruit contain essential coriander oil $(0.68-0.9 \%)$. This oil is utilized in soap production and in the textile industry. Bifora radians is multiplied in agrarian meadows. Coriandrum sativum is growing from on the edge of the sea $(20 \mathrm{~m})$ and on high mountains $(2144 \mathrm{~m})$ in Georgia. Coriander seems to have been cultivated in Georgia since at least the second millennium BC. Stem is straight, orbicular in section, with thin grooves, branchy from the bottom or only in the upper part, $20-70 \mathrm{~cm}$ tall. Flowers are $3-4 \mathrm{~mm}$ long. Fruit is globular, $2-5 \mathrm{~mm}$ in diameter, brownish yellow or stramineous. Blossoms in June-July and bears fruit in August. The Caucasus has 8 species of CWRs for agrarian Coriander.
\end{abstract}

Keywords: CWRs; GP1+2; Mountain heights; Scoring system; Vitamins

\section{Introduction}

Coriander - Coriandrum sativum L. (Apiaceae) is agricultural species and it is especially, field crop wild relatives occur in this biome. Roadsides, almost on all territory of Georgia are completelly covered by Aegilops cylindrica and Hordeum leporinum, more rarelly occurs in the region-Aegilops tauschii, Avena barbata, A. fatua, Beta corolliflora, Brassica elongata, Fragaria vesca, Linum austriacum, Medicago spp., Mentha aquatica, Raphanus rapinastrum, Setaria viridis, Satureja spicigera, S. laxiflora, Solanum nigrum. Agricultural land area is covered by species-Coriandrum sativum. Taxonomically the same species as crops are 11 species: Coriandrum sativum, Cornus mas, Corylus avellana, Medicago sativa, Mespilus germanica, Onobrychis transcaucasica, Prunus avium, Prunus cerasifera, Prunus spinosa, Rubus idaeus, Satureja spicigera. Diversity of CWRs of Georgia are in the results of the field work carried out in many regions in 2016 revealed CWR species having high conservation value. First step, when prioritization of CWRs have been done showed Coriandrum genus and 27 species having outstanding importance for conservation as CWRs with high scores according to methodology used in this investigation [1].
CWR species with wide range of distribution in rural and urban areas mainly on cultivated beds and road sides: Brassica elongata, Coriandrum sativum, Medicago sativa, Onobrychis transcaucasica, Vicia johannis. Diversity of CWR species studied in the Georgia has revealed many species of high conservation value. Cultivation and propagation methodology is determined for every target species, which will help to local farmers to cultivate CWRs in own grounds. This is especially important for fodder species, such as Coriandrum sativum and Bifora radians. To ensure in situ conservation of CWRs, establishment of nature reserves where CWRs of conservation value is distributed will be important in Georgia. We support idea to establish managed reserve in Erusheti Mountain systems where Aethusa cynapium has two populations [2].

In situ conservation of CWR species concentrated in rural areas, close to settlements and in agricultural fields, where soil is cultivated it is necessary to set up fenced territories with indication of conservation status of protected species. Local government and non-governmental organizations should be involved on this process. It is necessary to create data base on 
ex situ collections of CWRs in Georgia and abroad using standard computer software, so that the data will be incorporated in the international data bases and get accessible to wide range of specialists [3].

Education of local population should be undertaken to know which plants have special conservation value as relatives and even direct ancestors and progenitors of known and popular crops. This is possible due to publishing illustrated publications and dissemination of knowledge among local population. Legislation should be developed to determine priority status of important wild CWR species found in Georgia [4]. The plants should be protected and declared as plants having big importance as close relatives to popular field crops and their germplasm might be used in improvement of the quality of crop varieties. Monitoring is important to conduct as further investigation of CWRs in this region and create detailed data base including information on distribution, population status, ethnobotany and their use in folk traditional being.

\section{Methodology}

Genus Coriandrum involves the comparison of 'total' natural CWR species diversity as already actively conserved either in situ or ex situ. This is the basis for gap analysis, which can be divided into four consecutive steps [5].

\section{Step 1}

Circumscription of target taxon and target area: First, the taxonomic (e.g. genus, section or species) and geographical (e.g. global, regional, country or province) breadth of the analysis must be established.

\section{Step 2}

Assessment of natural diversity: The level of diversity occurring within the target taxon must be defined at the taxonomic, genetic or eco geographical levels, i.e. how many taxa occur in the circumscribed taxon, but also the inherent genetic diversity within those taxa.

\section{Step 3}

Assessment of current conservation strategies: The diversity occurring in situ can be compared to the diversity currently conserved in order to assess the efficiency of both in situ and ex situ conservation techniques.

\section{Step 4}

Reformulation of conservation strategy: Assessment of the effectiveness of current conservation coverage in relation to natural in situ diversity identifies the element of diversity that is under conserved, i.e. the 'gaps' in the existing conservation strategy and helps refocus the strategy to conserve the maximum diversity and fill these gaps. The revised priorities are likely to require complementary in situ and ex situ conservation actions to ensure the comprehensive conservation of the target taxon's gene pool.
According to this concept three Gene Pools are distinguished as follows: Primary Gene Pool (GP-1) within which GP-1A are the cultivated forms and GP-1B are the wild or weedy forms of the crop. Secondary Gene Pool (GP-2), which includes less closely related species from which gene transfer to the crop is possible but difficult using conventional breeding techniques. Tertiary Gene Pool (GP-3), which includes the species from which gene transfer to the crop is impossible, or if possible requires sophisticated techniques, such as embryo rescue, somatic fusion or genetic engineering.

The taxon group concept is used to establish the degree of CWR relatedness of a taxon. Application of the taxon group concept assumes that taxonomic distance is positively related to genetic distance. The CWR rank of taxon groups is defined as follows: Taxon Group 1a- crop. Taxon Group 1b-same species as crop. Taxon Group 2-game series or section as crop. Taxon Group 3 -same subgenus as crop. Taxon Group 4-same genus. Taxon Group 5-same tribe but different genus to crop.

Table 1: Scoring system for CWRs priority.

\begin{tabular}{|c|c|}
\hline Legends and Status & Score \\
\hline \multicolumn{2}{|l|}{ Threat (IUCN) } \\
\hline Critically endangered & 10 \\
\hline Endangered & 7 \\
\hline Vulnerable & 4 \\
\hline Near threatened & 2 \\
\hline Least concern & 0 \\
\hline \multicolumn{2}{|l|}{ Rarity } \\
\hline Present in one $10 \times 10 \mathrm{~km}$ & 10 \\
\hline Present in $2-510 \times 10 \mathrm{~km}$ & 7 \\
\hline Present in $6-2010 \times 10 \mathrm{~km}$ & 4 \\
\hline Present in 21-50 10x10km & 2 \\
\hline Present in $>5010 \times 10 \mathrm{~km}$ & 0 \\
\hline \multicolumn{2}{|l|}{ Endemicity } \\
\hline Only in Georgia & 10 \\
\hline Only in the Caucasus & 5 \\
\hline Only in South-east europe & 2 \\
\hline Throughout europe & 0 \\
\hline \multicolumn{2}{|l|}{$\mathrm{GP} / \mathrm{TG}$} \\
\hline Gene pool 1b/Taxon group $1 \mathrm{~b}$ & 10 \\
\hline Gene pool 2/Taxon group 2 & 6 \\
\hline Taxon group 3 & 4 \\
\hline Taxon group 4 & 2 \\
\hline Gene pool 3/Taxon group 5 & 0 \\
\hline
\end{tabular}

Thus, combined use of the gene pool and taxon group concept proposed above provide the best pragmatic means available to determine whether a species is a CWR and how 
closely related a CWR is to its crop. This scoring system (Table 1) wa;s studied in this work and this method was applied to wild Coriandrum species distributed on the territory of Georgia and the evaluation was used for field survey. The criteria to be scored are threat level determined according to IUCN categories. Rarity of species calculated as frequency of $10 \times 10 \mathrm{~km}$ grid squares where the species occurs. Endemicity was determined according to Key of Georgian Flora [6], the herbarium data and preliminary investigation on fields. Gene pool and taxon group identification was related to molecular study of species [7].

\section{Results and Discussion}

The applied scoring system to CWR of Coriandrum sativum individuals was selected according to the criteria, such as threat level, rarity and GP/TG and concepts determined as high score (14) for this species (Table 2).

Table 2: Scoring system of Coriandrum sativum.

\begin{tabular}{|c|c|}
\hline Legends and Status & Score \\
\hline \multicolumn{2}{|c|}{ Threat (IUCN) } \\
\hline Near threatened & 0 \\
\hline Rarity & 4 \\
\hline Present in 6-20 10x10km Endemicity \\
\hline \multicolumn{2}{|c|}{ GP1+2 } \\
\hline Only in the Caucasus & 10 \\
\hline \multicolumn{2}{|c|}{ Gene pool 1b/Taxon group 1b } \\
\hline Sum & 14 \\
\hline
\end{tabular}

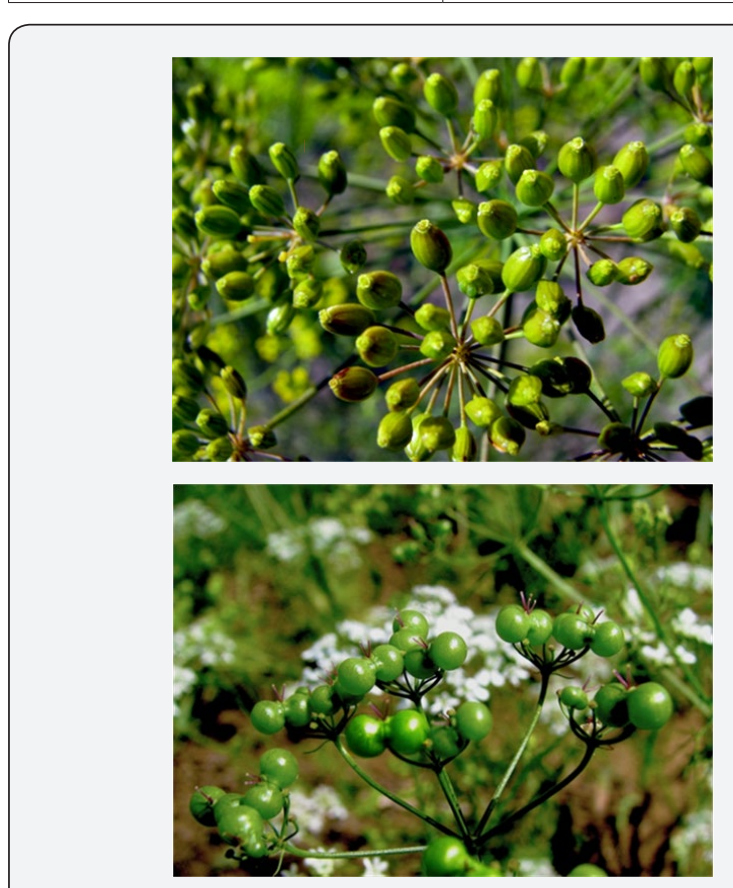

Figure 1: (A) Coriandrum sativum seeds are separate; (B) Two seeds of Bifora radians are planted.
Coriandrum sativum was shown that 19 of 27 priority CWR species represent the same species or direct ancestor of crop plants (GP-1b/TG-1b). This is especially important for fodder species, such as Coriandrum sativum, Aethusa cynapium, Bifora radians, Cicuta virosa, Conium maculatum, Physospermum cornubiense, Sium latifolium and Smyrnium cicutarium. Its 8 accepted species and 27 are the same synonym names in species as crops. Coriandrum sativum had other synonym name Coriandrum radians and herbs are represented by Bifora radians and it is very similar to Corianders (Figure 1). Bifora radians is multiplied in agrarian meadows of Meskheti. These all species are for food and as medicinal plants with many vitamins-A, B1, B2, B3, B5, B6, B9, C, E and K. The results have shown that 8 of 27 priority CWR species represent the same species or direct ancestor of crop plants (GP-1b/TG-1b). It was shown that 8 of 27 priority CWR species represent the same species or direct ancestor of crop plants (GP-1b/TG-1b). One species of 8 accepted species are the same species as crops: Coriandrum sativum (Table 3 ).

Table 3: Coriandrum genus of some species are accepted name and other species are as synonym names. These species are in family Apiaceae.

\begin{tabular}{|c|c|c|}
\hline S. $\mathrm{N}$ & Accepted Name & Synonym Name \\
\hline 1 & Aethusa cynapium L. & Coriandrum cynapium Crantz \\
\hline 2 & Bifora radians M.Bieb. & $\begin{array}{c}\text { Coriandrum radians (M.Bieb.) } \\
\text { Prantl }\end{array}$ \\
\hline 3 & Cicuta virosa $L$. & Coriandrum cicuta Roth \\
\hline 4 & Conium maculatum $L$. & Coriandrum cicuta Crantz \\
\hline 5 & Conium maculatum $L$. & $\begin{array}{l}\text { Coriandrum maculatum (L.) } \\
\text { Roth }\end{array}$ \\
\hline 6 & Coriandrum sativum $L$. & Bifora loureiroi Kostel. \\
\hline 7 & Coriandrum sativum $L$. & $\begin{array}{l}\text { Coriandrum diversifolium } \\
\text { Gilib. }\end{array}$ \\
\hline 8 & Coriandrum sativum $L$. & Coriandrum globosum Salisb. \\
\hline 9 & Coriandrum sativum $L$. & Coriandrum majus Gouan \\
\hline 10 & Coriandrum sativum $L$. & Coriandrum majus Garsault \\
\hline 11 & Coriandrum sativum $L$. & $\begin{array}{l}\text { Coriandrum sativum var. } \\
\text { afghanicum Stolet. }\end{array}$ \\
\hline 12 & Coriandrum sativum $L$. & $\begin{array}{l}\text { Coriandrum sativum var. } \\
\text { africanum Stolet. }\end{array}$ \\
\hline 13 & Coriandrum sativum $L$. & $\begin{array}{l}\text { Coriandrum sativum var. } \\
\text { anatolicum Stolet. }\end{array}$ \\
\hline 14 & Coriandrum sativum $L$. & $\begin{array}{l}\text { Coriandrum sativum var. } \\
\text { arabicum Stolet. }\end{array}$ \\
\hline 15 & Coriandrum sativum $L$. & $\begin{array}{l}\text { Coriandrum sativum subsp. } \\
\text { asiaticum Stolet. }\end{array}$ \\
\hline 16 & Coriandrum sativum $L$. & $\begin{array}{l}\text { Coriandrum sativum var. } \\
\text { asiaticum Stolet. }\end{array}$ \\
\hline 17 & Coriandrum sativum $L$. & $\begin{array}{l}\text { Coriandrum sativum subsp. } \\
\text { indicum Stolet. }\end{array}$ \\
\hline 18 & Coriandrum sativum $L$. & $\begin{array}{l}\text { Coriandrum sativum var. } \\
\text { indicum Stolet. }\end{array}$ \\
\hline
\end{tabular}




\begin{tabular}{|c|c|c|}
\hline 19 & Coriandrum sativum L. & $\begin{array}{c}\text { Coriandrum sativum var. } \\
\text { microcarpum DC. }\end{array}$ \\
\hline 20 & Coriandrum sativum L. & $\begin{array}{c}\text { Coriandrum sativum var. } \\
\text { pygmaeum Stolet. }\end{array}$ \\
\hline 21 & Coriandrum sativum L. & $\begin{array}{c}\text { Coriandrum sativum subsp. } \\
\text { vavilovii Stolet. }\end{array}$ \\
\hline 22 & Coriandrum sativum L. & $\begin{array}{c}\text { Coriandrum sativum var. } \\
\text { vavilovii Stolet. }\end{array}$ \\
\hline 23 & Coriandrum sativum L. & Selinum coriandrum Krause \\
\hline 24 & Coriandrum sativum L. & Sium coriaudrum Vest \\
\hline 25 & $\begin{array}{c}\text { Physospermum } \\
\text { cornubiense (L.) DC. }\end{array}$ & $\begin{array}{c}\text { Coriandrum aquilegiifolium } \\
\text { All. }\end{array}$ \\
\hline 26 & Sium latifolium L. & Coriandrum latifolium (L.) \\
\hline 27 & $\begin{array}{c}\text { Smyrnium cicutarium } \\
\text { M.Bieb. }\end{array}$ & $\begin{array}{c}\text { Coriandrum tordylium (Fenzl) } \\
\text { Bornm. }\end{array}$ \\
\hline
\end{tabular}

Coriandrum sativum $(2 \mathrm{n}=22)$ is the whole plant is nonpubescent. Root is thin, fusiform. Stem is straight, orbicular in section, with thin grooves, branchy from the bottom or only in the upper part, $20-70 \mathrm{~cm}$ tall. Leaves are light green. Root leaves wither early, set on long stalks, either whole with incised-dentate edges, or tri-lobed, or simply pinnate with orbicular-cuneate dentate leaflets. Lower cauline leaves are bipinnate with a few ovate leaflets, pinnately incised and wedge-shaped at the base. Middle and upper cauline leaves are sessile on oblong sheaths with wide film along the edge, bi- or tripinnate, with linear, almost filiform smooth-edged sharp lobules. Umbels with 3-5 bare rays are set on long peduncles. Swathe is absent or consists of one leaflet. Involucels are one-sided, more often with 3 very narrow leaflets. Petals are white or reddish. Outer (unpaired) petal in marginal flowers is $3-4 \mathrm{~mm}$ long, bilobate, with oblong lobes. 2 adjacent lateral petals are asymmetrically obovate, bilobate, with the anterior lobe much longer than the posterior one. 2 remaining petals are small, symmetrically obcordate. Inner flowers of the main umbel have slightly emarginate petals. Fruit is globular, $2-5 \mathrm{~mm}$ in diameter, brownish yellow or stramineous. Styles are elongated, deflected from one another at an acute angle, with a stigma incrassate at the tip. It is in flower from June to July, and the seeds ripen from August to September. The flowers are hermaphrodite (have both male and female organs) and are pollinated by Insects. The plant is self-fertile. It is noted for attracting wildlife. The fresh seed has a disagreeable and nauseous smell, but when dried it becomes fragrant, the longer it is kept the more fragrant it becomes. The overall distribution - Worldwide distribution, including Central and Atlantic Europe, the Mediterranean region, the Balkans, Asia Minor, and Iran. Occurs in North and South America as an ecdemic plant. This species occurs in the European region (Near- Baltic, UpperDnieper, Upper-Volga, Volga-Don, Lower-Don, Volga-Kama and Trans-Volga regions); the Far East (Ussuri region); the Caucasus (Ante-Caucasus and Trans-Caucasus, except the northern part); and Central Asia (Amu-Darya, Syr-Darya, Western Tien Shan and Mountainous Turkmenistan regions) [8].
Bifora radians $(2 \mathrm{n}=22)$ plant is $10-25 \mathrm{~cm}$ tall, rarely up to $60 \mathrm{~cm}$, with thin spindle-shaped root. Stem is glabrous, grooved, slightly curved geniculately at knots. Leaves are also glabrous, pinnatisect twice or three times, upper leaves are sessile with small flat sheaths and filiform or hair-like lobes, lower leaves are petiolate, with linear, sharp, entire lobes. Petioles are cylindrical and fluted from above. Inflorescence is a compound umbel, which has 3-8 glabrous rays up to $2.5 \mathrm{~cm}$ long, the bract is absent or unifoliate. Secondary umbels consist of 7-9 flowers, outer flowers are bisexual, enlarged, inner ones are staminal, smaller, petals are white, bracteoles are unilateral, with 2-3 subulatefiliform leaflets. This plant flowers in June-August, bears fruits in August. Fruits are globular, didymous and sinuate at both the top and bottom, greenish-brown with dark brown stripes, verruculose, $3 \mathrm{~mm}$ long and $6 \mathrm{~mm}$ wide. Seeds are pale yellow, $2.5 \mathrm{~mm}$ long, $2 \mathrm{~mm}$ wide. They germinate from a depth of no more than $12 \mathrm{~cm}$. The Caucasus, Meskheti, Crimea, Black Sea area. It is also distributed in the Mediterranean, Asia Minor, Iran and is an adventive plant in Middle Europe and North America [9].

Table 4: Coriander-Coriandrum sativum L. are in different Mountain heights in Georgia.

\begin{tabular}{|c|c|c|c|}
\hline S. N & Location & Coordinates & Elevation \\
\hline 1 & Kobuleti, Adjara & $\begin{array}{l}41^{\circ} 51^{\prime} 134 \mathrm{~N} \\
041^{\circ} 47^{\prime} 213 \mathrm{E}\end{array}$ & $20 \mathrm{~m}$ \\
\hline 2 & $\begin{array}{l}\text { Zubi V., Tsageri } \\
\text { district }\end{array}$ & $\begin{array}{l}42^{\circ} 34^{\prime} 108 \mathrm{~N} \\
042^{\circ} 40^{\prime} 252 \mathrm{E}\end{array}$ & $441 \mathrm{~m}$ \\
\hline 3 & $\begin{array}{c}\text { Shilda V., Kvareli } \\
\text { district }\end{array}$ & $\begin{array}{c}41^{\circ} 59^{\prime} 985 \mathrm{~N} \\
045^{\circ} 42^{\prime} 700 \mathrm{E}\end{array}$ & $491 \mathrm{~m}$ \\
\hline 4 & $\begin{array}{l}\text { Dusheti district, } \\
\text { Aragvi R. }\end{array}$ & $\begin{array}{c}42^{\circ} 55^{\prime} 082 \mathrm{~N} \\
043^{\circ} 01^{\prime} 207 \mathrm{E}\end{array}$ & $903 \mathrm{~m}$ \\
\hline 5 & $\begin{array}{l}\text { Akhaltsikhe-Adigeni } \\
\text { meadow }\end{array}$ & $\begin{array}{c}41^{\circ} 39^{\prime} 065 \mathrm{~N} \\
042^{\circ} 53^{\prime} 195 \mathrm{E}\end{array}$ & $1029 m$ \\
\hline 6 & $\begin{array}{l}\text { Laxamula V., Mestia } \\
\text { district, Zemo Svaneti }\end{array}$ & $\begin{array}{l}43^{\circ} 01^{\prime} 202 \mathrm{~N} \\
042^{\circ} 34^{\prime} 235 \mathrm{E}\end{array}$ & $1045 \mathrm{~m}$ \\
\hline 7 & $\begin{array}{l}\text { Magardeli V., Zkhumis } \\
\text { Temi R., Zemo Svaneti }\end{array}$ & $\begin{array}{c}43^{\circ} 00^{\prime} 405 \mathrm{~N} \\
042^{\circ} 33^{\prime} 465 \mathrm{E}\end{array}$ & $1215 \mathrm{~m}$ \\
\hline 8 & $\begin{array}{c}\text { Nakalakevi V., } \\
\text { Aspindza district }\end{array}$ & $\begin{array}{c}41^{\circ} 41^{\prime} 580 \mathrm{~N} \\
043^{\circ} 33^{\prime} 324 \mathrm{E}\end{array}$ & $1295 \mathrm{~m}$ \\
\hline 9 & $\begin{array}{l}\text { Nazuli V., Lashkheti V., } \\
\text { Zemo Svaneti }\end{array}$ & $\begin{array}{c}42^{\circ} 47^{\prime} 190 \mathrm{~N} \\
043^{\circ} 05^{\prime} 526 \mathrm{E}\end{array}$ & $1300 \mathrm{~m}$ \\
\hline 10 & $\begin{array}{c}\text { Doli V., Mestia district, } \\
\text { Zemo Svaneti }\end{array}$ & $\begin{array}{c}43^{\circ} 01^{\prime} 916 \mathrm{~N} \\
042^{\circ} 34^{\prime} 820 \mathrm{E}\end{array}$ & $1415 \mathrm{~m}$ \\
\hline 11 & $\begin{array}{c}\text { Labskaldi R., Zemo } \\
\text { Svaneti }\end{array}$ & $\begin{array}{c}42^{\circ} 59^{\prime} 800 \mathrm{~N} \\
042^{\circ} 34^{\prime} 007 \mathrm{E}\end{array}$ & $1650 \mathrm{~m}$ \\
\hline 12 & $\begin{array}{c}\text { Lalkhori V., Zemo } \\
\text { Svaneti }\end{array}$ & $\begin{array}{c}42^{\circ} 55^{\prime} 951 \mathrm{~N} \\
042^{\circ} 55^{\prime} 170 \mathrm{E}\end{array}$ & $1781 \mathrm{~m}$ \\
\hline 13 & $\begin{array}{l}\text { Ipari meadow, Cvirmi } \\
\text { V., Zemo Svaneti }\end{array}$ & $\begin{array}{c}43^{\circ} 00^{\prime} 901 \mathrm{~N} \\
042^{\circ} 48^{\prime} 139 \mathrm{E}\end{array}$ & $1895 \mathrm{~m}$ \\
\hline 14 & $\begin{array}{l}\text { Borjomi-Bakuriani } \\
\text { meadow }\end{array}$ & $\begin{array}{c}41^{\circ} 38^{\prime} 170 \mathrm{~N} \\
043^{\circ} 34^{\prime} 362 \mathrm{E}\end{array}$ & $2011 \mathrm{~m}$ \\
\hline 15 & $\begin{array}{l}\text { Ushguli-Lamaria V., } \\
\text { Zemo Svaneti }\end{array}$ & $\begin{array}{c}42^{\circ} 54^{\prime} 350 \mathrm{~N} \\
043^{\circ} 00^{\prime} 388 \mathrm{E}\end{array}$ & $2129 \mathrm{~m}$ \\
\hline 16 & $\begin{array}{l}\text { Diklo V. Omalo } \\
\text { district, Tusheti }\end{array}$ & $\begin{array}{c}42^{\circ} 38^{\prime} 029 \mathrm{~N} \\
045^{\circ} 62^{\prime} 877 \mathrm{E}\end{array}$ & $2144 \mathrm{~m}$ \\
\hline
\end{tabular}


Distribution in Georgia is occurs in different areas with height from $20 \mathrm{~m}$ to $2144 \mathrm{~m}$ (Table 4). It is in direction to in mountains dry areas along roads and in cultivated fields. Occurs on dry mountainsides and meadows, more often as a weedy plant in disturbed ecotopes. Occurs near homesteads, along roads, in orchards and in kitchen gardens. Easily grows in the wild. Is growing as weed in cultivated beds and wheat and barley fields. Occupies waste places and arable land, often by the sides of rivers. The plant prefers light (sandy) and medium (loamy) soils and requires well-drained soil. The plant prefers acid, neutral and basic (alkaline) soils and can grow in very alkaline soil. It can grow in semi-shade (light woodland) or no shade. It requires dry or moist soil.

\section{Threat assessment}

The herbicides used in the field might cause diminishing of the number of individuals and disappearance of wild populations of this species. Ex situ status-Seeds of this species but from Gare-Kakheti is delivered to the IPK Gatersleben gene bank. The populations in Georgia in situ status-The cultivated fields will be possible to protect to use herbicides, which will cause disappearance of this species.

Leaves of cultivated Coriandrum sativum is used as raw or cooked. They are used as flavouring in salads, soups, etc. Young shoots are edible (traditionally in the Caucasus under the name of 'kindzi') as a spicy herb. Fruit contains essential coriander oil $(0.68-0.9 \%)$. This oil is used in perfumery, for synthesis of a number of fragrant substances, in the soap industry, liqueur production, and medicine (usually to improve taste and smell of medicaments). Coriander fruit are also utilized to spice confectionary and food products (canned meat). After essential oil distillation, the raw stuff is used for producing fatty oil (up to $18 \%$ in fruit). This oil is utilized in soap production and in the textile industry. The cake (meal) remaining after fatty oil production is rich in protein and may be fed to livestock. Green parts of the plant also contain essential oils, but their composition is different from that of the fruit.
The use of herbicides and currently is not a big threat but in perspective it might cause diminishing of the number of individuals in wild populations. Mineral fertilizer might lead to the change of soil characters and disturb habitat of wild weed species including Coriandrum sativum. Reduce the decline of this species through appropriate habitat management. Coriandrum sativum should be declared as species of high economic value as wild edible plants. The sites will be protected as cultivated beds by leading of bioecological agriculture. Ex situ conservation of this species will be effective to collect seeds and keep in seed banks. The local population and governmental bodies responsible for the nature protection should be informed about high conservation value of this species.

\section{References}

1. Akhalkatsi M (2015) Erosion and Prevention of Crop Genetic Diversity Landraces of Georgia (South Caucasus). In: Ahuja MR, Mohan Jain S (Eds.), Genetic Diversity and Erosion in Plants. Springer International Publishing, Switzerland, pp. 159-187.

2. Akhalkatsi M (2015) Crop Wild Relatives of Georgia. In: Alexsidze G (Ed.), Agro biodiversity of Georgia (Catalog). Georgia Academy of Agricultural Sciences, Georgia, pp. 183-216.

3. Akhalkatsi M, Gvaladze G, Girgvliani T (2016) Situational Analyses of the Current State of Plant Genetic Resources Important for Food and Agriculture in Georgia (Caucasus Ecoregion). Agricultural Research \& Technology: Open Access Journal 2 (2): 1-5.

4. Akhalkatsi M, Girgvliani T (2015) Landraces and Wild Species of the Secale Genus in the Georgia (Caucasus Ecoregion). Agricultural Research \& Technology: Open Access Journal 1(4): 1-7.

5. Maxted N, Ford-Lloyd BV, Jury S, Kell Sh, Scholten M (2006) Towards a definition of a crop wild relative. Biodivers Conserv 15(8): 2673-2685.

6. Girgvliani T (2014) Upper Svaneti cultivars of cereals and legumes. Artanuji Publishers, Tbilisi, Georgia.

7. Asanidze Z, Akhalkatsi M, Henk AD, Richards CM, Volk GM (2014) Genetic relationships between wild progenitor pear (Pyrus L.) species and local cultivars native to Georgia, South Caucasus. Flora 209(19): 504-512.

8. Vavilov NI (1992) Origin and geography of cultivated plants. Cambridge University Press, Cambridge, UK.

9. Ketskhoveli N (1957) Zones of cultivated plants in Georgia. Georgian Academy of Sciences Press, Tbilisi, Georgia.
Your next submission with Juniper Publishers will reach you the below assets

- Quality Editorial service

- Swift Peer Review

- Reprints availability

- E-prints Service

- Manuscript Podcast for convenient understanding

- Global attainment for your research

- Manuscript accessibility in different formats

( Pdf, E-pub, Full Text, Audio)

- Unceasing customer service

Track the below URL for one-step submission https://juniperpublishers.com/online-submission.php 